Rok XVI (2021) | 1 (31) | S. 237-246

https://doi.org/10.12797/LV.16.2021.31.18

\begin{abstract}
Zbigniew Babik (1)
Uniwersytet Jagielloński, Kraków

zbigniew.babik@uj.edu.pl
\end{abstract}

\title{
WITOLD TASZYCKI A POLSKA ONOMASTYKA
}

Słowa kluczowe: Witold Taszycki, rozwój onomastyki w Polsce, historia językoznawstwa polskiego Keywords: Witold Taszycki, development of onomastics in Poland, history of Polish linguistics

Z nazwiskiem Witolda Taszyckiego zetknąłem się jeszcze w mych latach szkolnych, najwcześniej chyba w relacjach starszych kuzynów, wspominających wielkonakładowe Zasady pisowni polskiej... (tzw. „Jodłowski-Taszycki”) jako ulubione narzędzie nadgorliwych polonistów z prowincji używane do uprzykrzania życia młodzieży szkół średnich. W latach studenckich i później zaczęły do mnie docierać opowieści - snute głównie przez moich profesorów slawistów, pamiętających Taszyckiego ze swych czasów studenckich czy asystenckich - o ,jednoosobowej procesji”, w budynku uczelni poprzedzanej przez otwierającego kolejne podwoje legendarnego niepiśmiennego woźnego uniwersyteckiego Szymona, o trzęsących się nogach prof. Stanisława Urbańczyka zmierzającego na spotkania ze starszym o dekadę kolegą, o szczególnej, publicznie demonstrowanej nawet świadomą ",mową ciał” wzajemnej niechęci Taszyckiego i Zenona Klemensiewicza, o wypraszaniu z posiedzeń naukowych „swetrowców", zdaniem organizatora odzianych nieodpowiednio do powagi wydarzenia itd. ${ }^{1}$

1 Zob. też: Dunaj 2018: 17. Wspomniany tam językoznawca w oczach Taszyckiego zbyt młody na stopień i „oblany na egzaminie doktorskim” to zapewne dwudziestoośmioletni wówczas Władysław Lubaś (por. Lubaś 2005: 35).

Nagromadzone przykre wspomnienia znalazły częściowo ujście, niejako wbrew obowiązującej przecież i wówczas zasadzie nihil nisi bene, nawet tuż po śmierci Taszyckiego, we wspomnieniach uczniów, nieumiejących powstrzymać się od zamaskowanych pod eufemizmami krytycznych reminiscencji. Por. „Jego osobowość charakteryzowała się bowiem ciągłym niepokojem, chęcią 
Wyłonił się z nich obraz złowrogiego „Taszyca” ${ }^{2}$, jako nauczyciela i szefa może nie tyle szczególnie dolegliwego ze swej złośliwej natury³, co przywiązanego do pewnej hierarchii rzeczy i zdeterminowanego egzekwować jej przestrzeganie w sposób bezwzględny, niewyobrażalny dziś dla młodszych pokoleń, u których budzi już bardziej rozbawienie niż oburzenie. Jak sądzę, stać nas już na ocenę dokonywaną z należnego dystansu, wolną i od nadmiernej egzaltacji, właściwej często bezpośrednim wychowankom, i od osobistych uprzedzeń.

Witold Taszycki był historykiem języka polskiego i badaczem nazewnictwa polskiego, w mniejszej mierze polonistą normatywistą i filologiem słowiańskim. Jednak to właśnie chyba onomastyka polonistyczna stanowiła główne pole jego aktywności badawczej. Po ukończeniu krakowskich studiów wyższych zwrócił się najpierw ku najstarszemu staropolskiemu imiennictwu osobowemu, publikując rozprawę Najdawniejsze polskie imiona osobowe (1925), na podstawie której habilitował się w roku 1925. Praca ta (dziś o znaczeniu historycznym, gdyż zastąpiona przez prace Marii Malec i innych antroponomastów) w dekadach poprzedzających wydanie Słownika staropolskich nazw osobowych (SSNO) była często cytowana (także przez toponomastów) jako podstawowe źródło informacji o konkretnych, wykazanych w niej antroponimach. Jako profesor Uniwersytetu Jana Kazimierza rozpoczął Taszycki zbieranie materiałów do planowanego wielkiego słownika staropolskich nazw osobowych, kontynuowane po przenosinach do Krakowa, zwłaszcza po powołaniu w 1953 r. Pracowni Onomastycznej PAN, której kierownictwo objął (por. Taszycki 1955b, 1968). Wykształcił grono badaczy staropolskiej antroponimii, którzy w większości weszli w skład środowiska onomastycznego powołanego w 1973 r. Instytutu Języka Polskiego PAN ${ }^{4}$. Został redaktorem ukazującego się od 1965 r. SSNO, ukończonego już po jego śmierci, w drugiej połowie lat 80 ., jednego z najważniejszych wydawnictw ma-

kształtowania rzeczywistości po swojemu, według zasad racjonalnych. Tępił nerwowo bezmyślność, nieudolność a zwłaszcza nierzetelność, powierzchowność, uproszczone widzenie świata. Nienawidził lenistwa, pozorowania pracy. Dla ludzi reprezentujących te cechy stawał się po prostu nieprzychylny” (Lubaś 1981: 8); „Był dobrym choć surowym nauczycielem” (Rymut 1979: ostatnia). Z upływem czasu wspomnienia uczniów o Taszyckim coraz bardziej skupiały się jednak na pozytywach (por. np. Malec 2009).

2 Kolejne pokolenia nadal wyczuwają specyficzne nacechowanie tego nadanego przez ówczesnych studentów przezwiska, zwłaszcza jeśli skontrastować je z protekcjonalnym „Kuryłką” (mianownik „Kuryłko”), otrzymanym przez w sumie też zasadniczego bliskiego przyjaciela Taszyckiego jeszcze $\mathrm{z}$ lat lwowskich.

3 I tak np. we wrześniu 2016 r. współoczekująca na przystanku w Przegorzałach Elżbieta Borysiak zaskoczyła mnie ciepłym wspomnieniem o profesorze wysyłającym podwładne z pracowni onomastycznej do cukierni, a następnie częstującym zakupionymi przez nie ciastkami cały zespół.

4 Władysław Lubaś (2005: 45) wymieniał z tego grona: Marię Karpluk, Marię Malec, Zygmunta Klimka, Marię (Bobowską-)Kowalską, Kazimierę Warczewską-Klimkową, Adama Turasiewicza, Kazimierza Rymuta, Aleksandrę Cieślikową, Zofię Kowalik(-Kaletę), Andrzeja Koronczewskiego, Józefa Bubaka, Marię Gruszczyńską, Danutę (Jodłowską-)Wesołowską. Niektórych spośród tych badaczy nie poznałem ani osobiście, ani poprzez publikacje. 
teriałowych onomastyki polskiej (por. Malec 2009: 174), choć - wobec obserwowanego stałego postępu historycznej leksykografii źródłowej - nierejestrującego całości znanej dziś staropolskiej antroponimii.

Zaraz po wojnie Taszycki ogłosił swoją z perspektywy czasu najważniejszą pracę toponomastyczną - Słowiańskie nazwy miejscowe (ustalenie podziału) (1946). Wiele napisano o jej wpływie na teorię i praktykę badań toponomastycznych. Chciałbym tu jednak zwrócić uwagę na jej wpływ na rozwój praktyki badań polskich. Praca, jak wiadomo, w nawiązaniu do wcześniejszych spostrzeżeń historyków i językoznawców zaproponowała podział nazw miejscowych - w praktyce ojkonimów, rzadko stosuje się bowiem tę klasyfikację do systematyzowania innych typów nazw (ma to swoje głębsze powody) - na kilka odrębnych grup. Najbardziej podstawowy był podział na określenia ludzi i określenia terenu, co z racji elipsy członów określanych niezupełnie pokrywało się z podziałem ze względu na etymony - antroponimiczne lub apelatywne. Części z tych typów przypisano jednak stosunkowo wyraziste wykładniki formalne (sufiksy dzierżawcze, patronimiczne lub „służebne” *-bnikr, *arjb; pluralizacja antroponimów jako wykładnik rodowości) - i to właśnie zdeterminowało metodyczny aspekt analizy polskich nazw miejscowych, zwłaszcza że ton ich badaniom nadawali początkowo krakowscy współpracownicy lub uczniowie Taszyckiego. W największym skrócie, starano się najpierw zidentyfikować typ, do którego nazwa należała. Jeśli nie wchodziła w grę żadna z najbardziej wyrazistych grup formalnych (dzierżawcze, patronimiczne, rodowe, służebne), nazwę zaliczano do kategorii nazw topograficznych lub niejasnych. Oznaczało to rozpoczynanie badania nazwy od analizy „od końca”, w przeciwieństwie do intuicyjnej, „przednaukowej” analizy „od początku”, poprzez próbę rozpoznania morfemu leksykalnego. Takie podejście można uznać za symboliczne „unaukowienie” toponomastyki. Doceni to chyba każdy, kto miał możliwość skonfrontowania, jak krętymi ścieżkami podążały badania toponomastyczne chociażby w krajach wschodniosłowiańskich.

Witoldowi Taszyckiemu zawdzięczamy także zainicjowanie i promowanie zakrojonych regionalnie powojennych badań nad ojkonimią polską. Ze względu na rozległość terytorium Polski (czy nawet polskiego obszaru etnograficznego w jej granicach) nie sprawdziłyby się w praktyce przedsięwzięcia całościowego, a zarazem sprawnego opracowania nazewnictwa miejscowego w jednym wielotomowym wydawnictwie, znane m.in. z Czech (MJČ). Rozpoczęto zatem od opracowywania materiału z poszczególnych ziem historycznych czy przedrozbiorowych województw, a nawet poszczególnych typów nazw w ich granicach. Pierwszą taką monografię dał sam Taszycki (1951), była ona jednak poświęcona mało właściwie interesującej kategorii patronimików (na *-itj- i sporadycznie ${ }^{*}$-ęt-) z perspektywy historycznego Mazowsza. Kolejną opracowano w Poznaniu pod kierunkiem wywodzącego się z Krakowa S. Urbańczyka (Zierhoffer 1957); wbrew przedwojennej poznańskiej tradycji traktowania materiału toponomastycznego (mam na myśli głównie prace Mikołaja Rudnickiego) nawiązywała ona jednak ściśle do klasyfikacji Taszyckiego 
i wynikającego z niej podejścia metodycznego. W latach 6o. „rynek” ten został prawie całkowicie zdominowany przez krakowskich wychowanków Taszyckiego (Kamińska 1964-1965; Pawłowski 1965; Rymut 1967; Lubaś 1968), a prace ich w naturalny sposób stały się wzorcem dla późniejszych pokoleń toponomastów i tworzonych przez nich „szkół”.

Nie znaczy to, że były one wolne od wad. Najważniejsza wynikła z konieczności wydania bardzo obszernych tekstów rozpraw doktorskich w wersji skróconej, co osiągano poprzez odchudzanie serii zapisów i redukowanie do minimum objaśnień etymologicznych ${ }^{5}$. Kadłubowa dokumentacja, bywało, w prowadzała w błąd badaczy (w wielu wypadkach np. Andrzeja Bańkowskiego), którzy błędnie oceniali wymowę zaprezentowanych seriacji zapisów. Wspólnym mankamentem tych prac była też niedostateczna interpretacja nazw trudnych (pozostawiano je bez komentarza bądź forsowano próby niespełniające $\mathrm{w}$ istocie warunków brzegowych ${ }^{6}$ ). Incydentem zapewne przykrym dla Taszyckiego - jako opiekuna jednej z tych prac - było ukazanie się w Szwecji książkowej, mocno krytycznej z punktu widzenia warsztatu znawcy źródeł średniowiecznych (ale również językoznawcy toponomasty) recenzji monografii ojkonimów dawnego woj. sandomierskiego pióra Jerzego Nalepy (1973), prowokującej przedłużoną dyskusję (Pawłowski 1976), najcelniej podsumowanej przez A. Bańkowskiego (1975).

Jako badacze nazewnictwa geograficznego i osobowego Taszycki i jego uczniowie uprawiali onomastykę językoznawczą, względnie autonomiczną wobec kryteriów i realiów pozajęzykowych, nacechowaną jednak ostrożnością i starającą się nie opuszczać twardego gruntu historii pisanej nazwy. Stąd może nieufność względem nieposiadających zwykle kilkuwiekowej dokumentacji nazw obiektów o niższej randze, m.in. tzw. nazw polnych. Trwałą zasadą, przez dekady odróżniającą polską onomastykę choćby od nauki uprawianej za naszą wschodnią granicą, stało się dążenie do zgromadzenia możliwie pełnej dokumentacji historycznej, co zresztą ówczesny stan opracowania polskich źródeł historycznych w zasadzie już umożliwiał. Mniej uwagi poświęcano rozpoznawaniu ogólniejszych tendencji rozwojowych, których uwzględnienie mogłoby częściowo zrekompensować niepełną znajomość historii

5 Kopie maszynopisów tych prac doktorskich zostały pocięte lub rozpisane na fiszki i włączone do kartoteki planowanego słownika nazw miejscowych Polski, przez dłuższy czas pozostając jednak dostępnymi dla badaczy tylko na miejscu w Krakowie. Dopiero ta kartoteka, od pewnego czasu zdigitalizowana i dostępna zdalnie dla pracowników Instytutu Języka Polskiego PAN oraz osób z nimi współpracujących, daje wyobrażenie o rzeczywistej zawartości tych doktoratów.

6 Można tu mówić o niedostatecznej opiece promotorskiej. W monografii Lubasia w dobrych kilku przypadkach jako etymony średniowiecznych nazw geograficznych podawano terminy botaniczne lub zoologiczne zaczerpnięte z dzieła Erazma Majewskiego (1891), nie sprawdziwszy, że desygnaty nie występują w Polsce czy niekiedy nawet w Europie, a zatem odpowiednie terminy musiały zostać ukute przy biurkach botaników, zapewne nie wcześniej niż w XIX w. Prace Kamińskiej, Rymuta i Pawłowskiego szczęśliwie uniknęły tego potknięcia. 
i ewolucji nazw, a także doskonaleniu warsztatu badawczego. Widoczna była tendencja do zamykania się w „zaklętym kręgu” polszczyzny i polonistyki, ich źródeł, opracowań, materiałuㄱ. O ile na pionierskim etapie badań rzemieślnicze podejście dawało dobre efekty, z czasem dało się zauważyć pewne wyczerpywanie się traktowanej w taki sposób problematyki. Perspektywy dalszego rozwoju wymagały wejścia na nowe obszary, względnie poszerzenia horyzontów badawczych. Nadmierny, zrutynizowany empiryzm tego okresu został rychło dostrzeżony i krytycznie oceniony (Karaś 1978), nie miało to jednak wyraźnych konsekwencji praktycznych.

Pozostając jednym z niezbyt wówczas licznych profesorów językoznawstwa uprawiających onomastykę historyczną, został Taszycki członkiem, a następnie przewodniczącym Komisji Ustalania Nazw Miejscowych (KUNM, potem KUNMiOF), w latach bezpośrednio powojennych zajmującej się (re)polonizacją nazewnictwa na Ziemiach Zachodnich i Północnych. Odpowiadał za zmiany nazewnictwa śląskiego (i mazurskiego?), m.in. zdeterminował współczesną postać nazewnictwa sudeckiego, przeciwstawiając się wychodzącym od geografów czy entuzjastów turystyki górskiej spontanicznym, oddolnym próbom wprowadzenia do niego wołoskich elementów karpackich (Swoboda 2015) ${ }^{8}$. Można zauważyć, że w przeciwieństwie zwłaszcza do polonizującego nazewnictwo Pomorza i Nowej Marchii M. Rudnickiego Taszycki nie miał zupełnie oporów przed kalkowaniem odapelatywnych nazw oryginalnie niemieckich - inspirowanie się semantyką nazw niemieckich było bodaj najbardziej typową strategią polonizowania nazw terenowych na Śląsku. Komisja pracowała pod presją czasową, stąd adekwatność decyzji repolonizacyjnych w wielu wypadkach musi być dziś kwestionowana - niekiedy mylnie oceniano wymowę substytucyjnych przekazów ojkonimów, w przypadku nazw terenowych i wodnych często nie znano historycznych przekazów dawnych nazw staropolskich, kalkując późniejsze warianty niemieckie lub wprowadzając tzw. chrzty (por. np. Gołaski 2009; Swoboda 2014).

Taszycki jako przewodniczący KUNM uczestniczył zapewne w pracach przygotowawczych nad szeroko zakrojonym przedsięwzięciem zebrania całości używanego w terenie nazewnictwa geograficznego na słowiańskim obszarze etnograficznym

7 Odnosi się wrażenie, że znaczne w porównaniu z okresem przedwojennym wymuszone ograniczenie kontaktów - także przecież z krajami słowiańskimi bloku wschodniego - natrafiło tutaj na spontanicznie rozwinięty podatny grunt.

Przed kilku laty uderzył mnie, przeglądającego fascykuły „Onomastików” z lat 6o., kontrast między działami Recenzje i polemiki (liczne recenzje prac obcych) i Stan badań nazewniczych (zwykle kilka spotkań na forum międzynarodowym rocznie) a nieodmiennie autarkiczną praktyką badawczą artykułów i rozpraw publikowanych w czasopiśmie przez autorów polskich.

8 Lektura odpowiednich haseł SNGŚ przekonuje, że przedniemieckie nazewnictwo górskie polskiej części Sudetów (i jego zakres, zapewne bardzo niewielki) właściwie pozostaje nierozpoznane. Obecne nazewnictwo polskie ma charakter praktycznie całkowicie sztuczny, chociaż semantycznie bardzo ściśle nawiązuje do wcześniejszego niemieckiego. 
w granicach powojennej Polski (tzw. akcja UN-owska, zob. Babik 2019; por. też Pawłowski 1965: 6-9; Lubaś 2005: 33-35). Nazwisko jego jako redaktora całości serii widnieje na stronie redakcyjnej wszystkich wydanych 142 tomików powiatowych, nie mam natomiast jasności, jak wielki wpływ wywarł na koncepcję przedsięwzięcia (być może był (współ)autorem instrukcji dla eksploratorów, o której istnieniu zebrałem informacje) ${ }^{9}$. Rzeczywisty wkład Taszyckiego w te prace pozostaje dla mnie nieznany (przykładowo: nie wiem, czy recenzował niektóre maszynopisy). Udało się ustalić, że inicjatywa wyszła prawdopodobnie od urzędników ministerialnych w początkach lat 50 . (oficjalnymi ${ }^{10}$ celami były "uporządkowanie nazewnictwa” i „usunięcie naleciałości obcych z czasów zaborów”, czego w praktyce nie zawsze przestrzegano). Zdecydowano, że wysłani zostaną w teren eksploratorzy z kręgu młodych językoznawców; najprawdopodobniej nie prowadzono akcji ankietowej, natomiast przygotowane na podstawie materiałów spisy były jeszcze przeglądane i dopełniane przez lokalne organy samorządu. W przypadku chociażby niektórych powiatów województwa łódzkiego ta konsultacja w terenie przyczyniła się do znacznego wzbogacenia zawartości tomików wydanych drukiem. Wydaje mi się, że Taszycki, jako historyk nazewnictwa o nachyleniu jednak „antykwarycznym”, nie miał dużego zrozumienia dla potencjału poznawczego współczesnego nazewnictwa terenowego. Niezależnie od tego nie ponosi natomiast odpowiedzialności za mało chwalebne dalsze losy nieopublikowanych materiałów tej akcji (Babik 2019: 305-309).

W 1955 r. wyszedł drukiem pierwszy tom czasopisma „Onomastica” (z podtytułem „Pismo poświęcone nazewnictwu geograficznemu i osobowemu”), którego pomysłodawcą był wprawdzie Stanisław Rospond (por. Rymut 2005: 5), redaktorem naczelnym został jednak właśnie Taszycki (funkcję tę pełnił do tomu 20. (1975) włącznie, redaktorem honorowym pozostał aż do śmierci). Było to pierwsze w krajach słowiańskich czasopismo poświęcone wyłącznie onomastyce, choć rychło pojawiły się podobne w Czechosłowacji, Jugosławii i ZSRR (nie wszystkie zrazu ukazywały się regularnie jako roczniki). Obok autorów polskich publikowali w nim badacze z innych krajów, głównie bloku wschodniego (inni pojawili się z opóźnieniem), nigdy jednak - co nie dziwi - nie stało się czasopismem w pełni międzynarodowym, z przewagą autorów spoza Polski. W latach 70. i 80. (częściowo także 90.) sprawnie funkcjonował w nim dział sprawozdawczo-recenzyjny (publikowano, zależnie od intencji autorów, zarówno recenzje sprawozdawcze, jak i obszerne polemiczne teksty warsztatowe), dość dobrze informujący o nowościach onomastycznych z kraju i zagranicy, którego skurczenie się w ostatnich dekadach należy przyjąć z żalem. Czasopismo istnieje do dziś bez dłuższych przerw, przekroczyło już 6o wydanych tomów,

9 Por. jednak Rymut 2003: 315, gdzie mowa o kierowaniu przezeń całą akcją.

10 Rzeczywistym zaś zapewne uzasadnienie dalszego istnienia Komisji wobec rozważanej już w roku 1950 (por. Gołaski 2009: 262) jej likwidacji wobec wykonania głównego z powierzonych jej zadań. 
chociaż zmiana podtytułu („[...] oraz innym nazwom własnym” od t. 47 (2002), „Pismo poświęcone teorii i interpretacji nazw własnych” od t. 59 (2015) - za sugestią Rudolfa Šrámka) wskazuje na pewne przesunięcie spektrum zainteresowań kontrybutorów. Sam redaktor naczelny miał decydujący wpływ na politykę pisma i kwalifikację nadsyłanych tekstów do druku (instytucja peer review w praktyce wówczas nie funkcjonowała), natomiast własnymi pracami zasilał je raczej skromnie.

Najbardziej chyba znanym i najczęściej cytowanym tekstem Taszyckiego zamieszczonym na łamach „Onomastików” jest inaugurujący pismo artykuł Historia i znaczenie nazwy Wawel (1955a). Sformułowano w nim oryginalną koncepcję wyjaśnienia tej i pokrewnych (Wąwel-) nazw polskich, rekonstruując i próbując objaśnić apelatyw ${ }^{*}$ waqwel $<{ }^{\star} Q-v \sigma l-b$ 'suche, wzniesione miejsce wśród wód i mokradeł'. Rekonstrukcja taka budzi niestety zastrzeżenia, przede wszystkim z racji niskiej wiarygodności przejętej od M. Rudnickiego rekonstrukcji indoeuropejskiego pierwiastka * vel- 'wilgoć, woda' (rekonstruowanego głównie z realnych postaci z różnymi determinatywami spółgłoskowymi), a także abstrahowania na poziomie interpretacji od obecności w polszczyźnie somatyzmu wąwel 'wole', potwierdzonego średniowieczną glosą kronikarską (ibid.: 42) i wiarygodnie zafiksowanego w gwarach Rzeszowszczyzny w czasach nam nieodległych (Łopaciński 1899: 926) ${ }^{11}$. Wyraz o znaczeniu 'wole ludzkie lub zwierzęce' mógł, jak wiele somatyzmów, wykształcić wtórne znaczenie topograficzne (np. *'wybrzuszenie terenu'), niesporo zaś byłoby oddzielać go od potencjalnie współrdzennego synonimu ${ }^{\star}$ volje (derywat ${ }^{*} Q$ - $v \sigma l-j b^{12}$ łączyłbym z tymże pierwiastkiem ${ }^{\star}(s)$ uel- 'nabrzmiewać' (?), rekonstruując wyjściowe znaczenie 'nabrzmiały w środku, od środka'). Paradoksalnie zatem rekonstrukcja semantyki apelatywu topograficznego wyprowadzona przez Taszyckiego z semantyki rozpoznanych przezeń członów złożenia mogła niewiele odbiegać od rzeczywistej.

Inną inicjatywą Taszyckiego, której przydatność praktyczną docenili i którą podjęli następcy, były prace nad bibliografią onomastyki polskiej. Zawdzięczamy mu zainicjowanie (wraz z Adamem Turasiewiczem i Mieczysławem Karasiem) i ukończenie prac nad bibliografią najstarszej literatury onomastycznej (do roku 1958), ogłaszaną sukcesywnie w belgijskiej „Onomie” i jako publikacja zwarta w Polsce. Czuwał także nad przygotowaniem dalszego ciągu tego dzieła, od roku 1959 do 1970. Po śmierci Taszyckiego kontynuowano wydawanie bibliografii w interwałach dziesięcioletnich, ostatnio (Iwona Nobis) pięcioletnich. Należy podkreślić, że pol-

11 Znaczenia wyrazu w słowniku Franciszka Giedroycia (1933: 426: 1. 'tumor, guz, opuchnięcie', 2. 'struma') mogą być wtórne względem nich. Kontekst odpowiedniego fragmentu Kroniki wielkopolskiej wskazuje jednak jasno, że kronikarz pisał o powiększeniu tarczycy wynikłym z niedoboru jodu.

12 Morfem ${ }^{*} v a l-$ można wyprowadzać ze stopnia zanikowego antekonsonantycznego $\left({ }^{*} u l C\right.$ - $>$ ${ }^{*} u u l C-$ lub ${ }^{*} u i l C-$, z późniejszą labializacją samogłoski) lub antewokalicznego $\left({ }^{*} u l V->{ }^{*} v a l V-\right.$, z późniejszą protezą labialną). Pierwiastek ${ }^{\star}$ suel- 'nabrzmiewać' nie występuje jednak werbalnie poza językami germańskimi i może italskimi, gdzie nie ukazuje się też $\mathrm{w}$ formach bez ${ }^{*} s-$. 
ska bibliografia onomastyczna aktualnie opracowywana jest bardzo sprawnie, nie mniej sprawnie niż inne informujące o aktywności polskich onomastów zestawienia bibliograficzne (np. „Linguistic Bibliography”).

W przeciwieństwie do choćby Jerzego Kuryłowicza Taszyckiego nieszczególnie pociągały rozważania teoretyczne. Należy jednak odnotować rozprawę Stosunek onomastyki do innych nauk humanistycznych (1963), w której wypowiedział się przeciwko żywym wówczas jeszcze tendencjom do traktowania onomastyki jako nauki pomocniczej historii (a z takiej tradycji właściwie wyszedł po części jako onomasta) czy, przeciwnie, jako odrębnej dyscypliny humanistycznej równorzędnej niejako z językoznawstwem. Trudno zaprzeczyć, że nazwy własne są pewną szczególną grupą leksyki, wobec czego nauki o nich wyprowadzać poza obręb językoznawstwa nie można. Dzisiaj, gdy językoznawstwo przyjęło się rozumieć szerzej niż jakieś 6o-70 lat temu, dyskusja nad statusem onomastyki straciła na znaczeniu, nie tylko z perspektywy polskiej. W naszej humanistyce do nauk pomocniczych historii nikt jej już chyba nie zalicza, przynależność onomastyki do językoznawstwa została ugruntowana także przez wieloletnią praktykę instytucjonalną.

Mimo iż badania nazewnicze były już wcześniej uprawiane przez wybitnych przedstawicieli lingwistyki polskiej czy krakowskiej, pod koniec życia był Taszycki uważany właściwie za (ojca) założyciela ówczesnej onomastyki polskiej. Takie stanowisko prezentowano również we wspomnieniach powstałych później (np. Rymut 1998: 6; Cieślikowa 2010: 6). Można wprawdzie dyskutować, czy jego zasługi na polu wzmocnienia i zapewnienia ciągłości zinstytucjonalizowanej onomastyki były większe niż zasługi chociażby jego ucznia i następcy Kazimierza Rymuta, wieloletniego szefa środowiska onomastycznego skupionego w IJP PAN. Rymut był jednak tylko następcą i kontynuatorem kierunku wytyczonego przez Taszyckiego, zwłaszcza jeżeli chodzi o podejście do zjawisk uważanych przez tego ostatniego za właściwy przedmiot zainteresowania uprawianej przez siebie onomastyki - nazewnictwa geograficznego i osobowego, które to badania nadal rozwijane są w polskich środowiskach onomastycznych. Taszyckiemu zawdzięczamy zaś tak stworzenie i ukształtowanie środowiska, jak i wypromowanie pewnego wzorca postępowania badawczego, do którego - mimo lokalnych czy przejściowych odchyleń - nawiązywało grono onomastów o bardziej tradycyjnych zainteresowaniach.

My wszyscy z niego. 


\section{Literatura}

ВАвIK Z., 2019, Tzw. akcja UN-owska (1952?-197o?) - projekt, przebieg, efekty, próba oceny, „Onomastica” 63, s. 291-313, [on-line:] http://dx.doi.org/10.17651/ONOMAST.63.16.

BAŃkowski A., 1975, [rec.] Jerzy Nalepa: Opuscula Slavica. 2. Krytyczne i metodyczne uwagi o nazwach miejscowych dawnego województwa sandomierskiego, Lund 1973, „Poradnik Językowy" nr 8, s. 447-457.

Cieślikowa A., 2010, Witold Taszycki (20 VI 1898-8 VIII 1979), „Onomastica” LIV, s. 5-7.

Dunaj B., 2018, Mieczysław Karaś - nauczyciel, przełożony, inspirator badań, człowiek (wspomnienia), [w:] R. Przybylska, M. Rak, A. Kwaśnicka-Janowicz (red.), Historia języka, dialektologia i onomastyka w nowych kontekstach interpretacyjnych, Kraków, s. 15-23.

Giedroyć F., 1933, Polski słownik lekarski, t. 2: P-Ż, Warszawa.

GoŁAski J., 2009, Ustalanie $i$ wdrażanie nazw obiektów fizjograficznych na Ziemiach Zachodnich i Północnych Rzeczypospolitej Polskiej, „Onomastica” LIII, s. 261-269.

KamiŃsKa M., 1964-1965, Nazwy miejscowe dawnego województwa sandomierskiego, cz. 1-2, Wrocław - Warszawa - Kraków.

KARAś M., 1978, O niektórych problemach onomastyki polskiej, „Onomastica” XXIII, s. 7-23.

Lubaś W., 1968, Nazwy miejscowe południowej części dawnego województwa krakowskiego, Wrocław - Warszawa - Kraków.

LubAś W., 1981, Witold Taszycki (20 VI 1898-8 VIII 1979), „Biuletyn Polskiego Towarzystwa Językoznawczego" XXXVIII, s. 5-9.

Lubaś W., 2005, W stronę przeszłości, „Onomastica” L, s. 31-47.

ŁopacıŃsKi H., 1899, Przyczynki do nowego słownika języka polskiego, „Prace Filologiczne” V, s. 681-976.

MajewsKi E., 1891, Słownik nazwisk zoologicznych i botanicznych polskich [...] etc., t. 1: Słownik polsko-łaciński, Warszawa.

Malec M., 2009, Witold Taszycki (1898-1979), „LingVaria” nr 4 (8), s. 171-178.

MJČ: A. Profous, Místní jména v Čechách: jejich vznik, pưvodní význam a změny (współpr. V. Šmilauer, J. Svoboda), t. 1-5, Praha 1947-1960.

NalePa J., 1973, Opuscula Slavica 2. Krytyczne i metodyczne uwagi o nazwach miejscowych dawnego województwa sandomierskiego, Lund.

PAwŁowski E., 1965, Nazwy miejscowe Sądeczyzny, t. 1: Ogólna charakterystyka nazewnictwa miejscowego Sądeczyzny, Kraków.

Pawıowski E., 1976, [rec.] Nalepa 1973, „Onomastica” XXI, s. 246-252.

Rymut K., 1967, Nazwy miejscowe północnej części dawnego województwa krakowskiego, Wrocław - Warszawa - Kraków.

Rymut K., 1979, Witold Taszycki (20 VI 1898-8 VIII 1979), „Onomastica” XXIV [4 strony niepaginowane jako wklejka na początku tomu].

Rymut K., 1998, Witold Taszycki - w setna rocznicę urodzin, „Onomastica” XLII, s. 5-10.

Rymut K., 2003, Działalność Komisji Ustalania Nazw Miejscowych i Obiektów Fizjograficznych w latach 1978-2003, „Onomastica” XLVIII, s. 315-324.

Rymut K., 2005, Pięćdziesięciolecie Onomastików, „Onomastica” L, s. 5-9.

SNGŚ: Słownik etymologiczny nazw geograficznych Śląska, t. I, red. S. Rospond, t. II-III, red. S. Rospond, H. Borek, t. IV, red. H. Borek, od t. V, red. S. Sochacka, t. I-XVII, Warszawa - Wrocław - Opole 1970-2017. 
SSNO: Słownik staropolskich nazw osobowych, t. I-VI, red. W. Taszycki, t. VII, red. W. Taszycki, M. Malec, Wrocław 1965-1987.

Swoвоda P., 2014, Nazwy z odzysku, „Ha!art” 48, s. 42-44.

SwoвоDA P., 2015, Skuwanie niemieckiego tynku, „Rzeczpospolita”, dodatek „Plus Minus” 125, s. 11-12.

TAszycki W., 1925, Najdawniejsze polskie imiona osobowe, Kraków.

TAszycki W., 1946, Słowiańskie nazwy miejscowe (ustalenie podziału), Kraków.

Taszycki W., 1951, Patronimiczne nazwy miejscowe na Mazowszu. Z mapa, Kraków.

TAszycki W., 1955a, Historia i znaczenie nazwy Wawel, „Onomastica” I, s. 41-59.

TASZYCKI W., 1955b, Stan prac nad słownikiem staropolskich nazw osobowych, „Onomastica” I, s. $193-198$.

TASZYCKI W., 1963, Stosunek onomastyki do innych nauk humanistycznych, „Onomastica” VIII, s. 1-19.

TAszYCKi W., 1968, Jeszcze słów kilka o początkach Słownika staropolskich nazw osobowych, „Onomastica” XIII, s. 343-344.

Zierhoffer K., 1957, Nazwy miejscowe północnego Mazowsza, Wrocław.

\section{Witold Taszycki and Polish Onomastics \\ Summary}

The author of the article discusses the merits of Witold Taszycki, professor of the Jan Kazimierz and Jagiellonian universities (1898-1979), from the perspective of a contemporary Polish onomastician of the middle generation. The author mainly focused on Taszycki's way of organizing the environment and planning team research on Polish names of people and places. It is justified to think that it was Taszycki, not so much with his own works in the field, but especially through selecting and educating the staff, who, to the greatest extent, determined the present form and research directions of this discipline in Poland. 